Cruz-Martínez, Gibrán (2016). Is there a Common Path that could have Conditioned the Degree of Welfare State Development in Latin America and the Caribbean? Bulletin of Latin American Research. DOI: 10.1111/blar.12556

\title{
Is there a Common Path that could have Conditioned the Degree of Welfare State Development in Latin America and the Caribbean?
}

\author{
Gibran Cruz-Martinez \\ gibrancm@uia.no
}

\begin{abstract}
The purpose of this paper is to re-examine from a multidimensional perspective the possible existence of a single path that could have conditioned the degree of welfare state development (WSD) in Latin America. Economic/industrial development, trade-openness, democracy and the strength of leftist parties-labour movement are used as explanatory variables in the qualitative comparative analysis. In contrast to previous findings, this paper shows that there is no evidence of a common path followed by countries with a relatively high/medium WSD. Nevertheless, countries that experienced a low economic/industrial development combined with a low democratic experience were conditioned to have a low WSD.
\end{abstract}

Keywords: welfare state, Latin America, multidimensional welfare index, QCA, social spending, PCA

\section{Introduction}

Welfare state scholarship has been interested in examining a diverse set of aspects of Latin American and Caribbean emerging welfare states. We know that welfare programmes and institutions are not a novelty in Latin America. The first social welfare programmes appear about one hundred years ago (i.e. 1920's) in countries such as Argentina, Brazil, Chile, Cuba, 
Puerto Rico and Uruguay (Mesa-Lago, 1994; Haggard and Kaufman, 2009; Cruz-Martinez, 2015). Martinez-Franzoni (2008) and Barba Solano (2009) have examined the different welfare regimes in the region to explain the role of markets, state and family in the allocation of social risks and the production of welfare. Pribble (2013) revealed the importance of electoral competition and political parties to explain the different paths of universalistic social policy reforms.

Additional scholars have proposed paths towards universalistic social policy reforms. What started with basic universalism (Molina, 2006) was recently developed as distinct public policies and regulatory frameworks recommendations to expand the coverage and benefits of entitled universal social protection (Cecchini et al., 2015). In his pioneer work, Segura-Ubiergo (2007) was able to identify a common path of political and economic conditions that could explain the different levels of welfare effort in Latin America.

To reach this conclusion, Segura-Ubiergo used the main explanatory theories of the European welfare state, plus the 'democratic experience' as an additional explanatory variable. However, one of the limitations of this study was the operationalization of the dependent variable using mainly indicators of social spending to construct the composite indicator of welfare effort. According to Olaskoaga et al. (2013) welfare effort has been the favoured measure for comparisons across space and time of the level of welfare state development. Nevertheless, using just social spending indicators is subject to criticism because of the over-riding importance given to this one dimension.

The purpose of this paper is to re-examine Segura-Ubiergo's (2007) puzzle after operationalizing the dependent variable by its multidimensional reality. In other words, to inquire from a multidimensional perspective the possible existence of a single path that could have conditioned the degree of welfare state development in Latin America and the Caribbean. The multidimensional welfare index (MWI) is used as the indicator of welfare 
state development. The term welfare state development refers to the progress and institutionalisation of welfare programs that address social risks of the population in order to assure a common well-being. Eight indicators from three welfare state dimensions shape the MWI. Principal components analysis (PCA) was used to summarise the initial dataset of eight indicators in a composite index, trying to lose as little information as possible.

The explanatory variables are four political and economic conditions, which according to the literature are useful to explain the degree of welfare state development. The political conditions considered are the democratic experience and the strength of the labour movement and leftist parties. The economic conditions pondered are the level of economic/industrial development and trade openness. Following the academic literature and the results of SeguraUbiergo the dependent variable is expected to be positively related with the democratic experience, the strength of the labour movement and leftist parties, and the economic/industrial development. While the relationship between trade openness and the MWI is expected to be negative.

Qualitative comparative analysis (QCA) is used to test the existence of a common path that could have conditioned the degree of welfare state development in seventeen countries of the region. The period considered in the MWI is the consolidation and expansion era of the Latin American welfare state, since the 1970's to the early 2000's. Meanwhile economic and political conditions used as explanatory variables refer to the pre-globalisation period, where the welfare state in the region began to originate and develop (1940's-1970's). On this period the prevailing model of economic development was the state-led industrialisation model (Bértola and Ocampo, 2012). It is necessary to consider path-dependency theory because of its practicality to point out the relevance of knowing that what occurs at first in time can affect the possible outcomes of a sequence of events occurring at a later point in time (Pierson, 2000). 
The paper is organised as follows. The next section briefly presents the methodology and results of the multidimensional welfare index. The political and economic conditions used as explanatory variables are addressed in the following section, highlighting their relationship with the welfare state development. Later on the paper briefly introduces the qualitative comparative analysis, the research technique used to examine the paths followed by countries during the pre-globalisation era. The fifth section presents the main results of the paper and in addition the contrasts with the findings of Segura-Ubiergo. The article finalise with a general conclusion.

\section{The Multidimensional Welfare Index as the dependent variable}

The welfare state from Latin America and the Caribbean could be best described as an emerging welfare state (Huber and Stephens, 2012). Previously, Esping-Andersen (1996) used the term 'welfare state in transition' while Riesco (2009) referred to 'developmental welfare state in the making'. Meaning that their welfare programmes and institutions are not yet as developed as their counterparts in Europe. In general, the state guarantees a basic minimum of social protection but in many cases the protection is limited, targeted and not perceived as an entitlement. As it was previously noted, the multidimensional welfare index (MWI) shows the level of development among the emerging welfare state in the region.

This new index is multidimensional in that it has eight indicators relating to three dimensions of welfare: social spending, coverage of welfare programs and outcomes of welfare institutions (see Table 1 for the list of indicators). Using principal component analysis (David Roberts function pca(x, cor=TRUE) under library(labdsv) in $R$ ), the eight indicators were reduced to three individual welfare indexes (SSDI, CDI, ODI); each index representing one of the three welfare dimensions.

\section{-Table 1-}


The aim of principal component analysis is to explain the largest possible variability in an initial set of variables with the fewest possible components (Uriel Jiménez, 1995). The high degree of correlation among the indicators allowed using only the first principal component as the index for each of the three welfare dimensions. This technique can be applied only when a significant correlation exists in the initial dataset, and of its limitations is the high sensitivity to the presence of outliers. The determinant test of the correlation matrix and the Bartlett test of sphericity were used to confirm the statistical relevance of the initial data for PCA.

The three welfare indexes were standardised to make the data more comprehensible (1.0 represents the country with the most developed welfare dimension, and 0.0 the least developed). Through an arithmetic mean each individual index was assigned the same weight in the construction of the MWI (i.e. 33,3per cent). Meanwhile the weights of the initial 8 indicators that form the individual indexes are assigned by the PCA (loadings matrix).

The results of the index account for more than 75 per cent of the data variance, so it could be considered a good summary index (see Cruz-Martinez (2014) for more details on the methodology and results). Table 1 shows the results of the individual indexes for each country, as well as the results of the MWI.

On Table 1, countries are grouped according to their MWI score. A MWI result between 0.66-1.00 indicates the country have a relatively high welfare state development. A MWI results between 0.33-0.65 denotes an intermediate welfare state development. Finally, a MWI score between 0.00-0.32 implies a relatively low welfare state development.

Before confirming or rejecting Segura-Ubiergo's findings, it will be necessary to proceed with the theoretical discussion on the respective economic and political conditions. 


\section{Theoretical analysis on the economic and political conditions as explanatory variables}

According to Segura-Ubiergo (2007: 31,38) there are four theories that seek to explain the emergence and development of the welfare state: (a) theories that emphasise the effects of economic development and industrialisation; (b) theories that focus on the relationship between trade openness and the expansion of the welfare state; (c) theories that highlight the importance of the labour movement and workers' representation in socialist parties; and (d) theories that consider democracy as an explanatory variable in the development of the welfare state.

\section{Economic/industrial development}

The 'logic of industrialism' and the 'Wagner Law' argue that the welfare state emerges in the process of industrialisation, which generated major transformations on the socioeconomic structures and produced ruptures in the work-family relations (Segura-Ubiergo, 2007: 32). Esping-Andersen (1990) had already raised this when he argued from the structuralist perspective, that industrialisation makes necessary and possible the development of social policy. Necessary because the market is not an adequate substitute for correcting the destruction of pre-industrial modes of social reproduction as it only covers the ones who can participate in it; and possible because of the emergence of modern bureaucracy as a form of universal rational and effective organisation.

Industrialism and the generalisation of wage labour also generalised the vulnerability of workers to be laid off or dismissed by market forces. Not only unemployment began to be a problem but also the movement of employees between 'good jobs' and 'bad jobs' (Atkinson, 1995: 204). Wilensky (1975: 13) specifically addressed the logic of industrialism to point out that economic growth and its direct outcomes are one of the main causes of the 
widespread emergence of what we call today the welfare state. Lamartina and Zaghini (2011) through a study with twenty-three member countries of the OECD in the period from 1970 to 2006 confirms the validity of the Wagner's Law and the positive relationship between public spending to gross domestic product (GDP).

The cases are analyzed in the QCA according to their average GDP per capita at purchasing power parity (PPP) and 2005 constant prices. Countries with a GDP per capita above the sample mean are considered as countries with a relatively high economic/industrial development, while countries with a GDP per capita below the sample mean are considered as countries with a relatively low economic/industrial development.

The term 'relatively' will continue to be used in the following three variables (i.e. trade openness, democratic experience, and strength of labour movements and leftist parties) in order to emphasise that the results are relative to the region, and specifically to the seventeen countries included in the analysis. Table 2 shows the results of the countries between 1950's and 1970's.

\section{-Table 2-}

While GDP per capita is one the most widely used indicators in international comparisons on development studies (Bregar et al., 2008), there is still a dilemma about which is the best way to measure economic development. Bauman (2014) criticise the use of GDP as an indicator of economic development, economic growth and/or happiness, mainly because it does not take into account income inequality. In addition the author criticises the GDP as a utilitarian indicator of welfare, arguing that happiness is presented as the possibility of owning and enjoying material goods.

While the average GDP per capita does not directly show the economic development in a period, it is expected that a higher GDP comes along with higher production of wealth and higher level of industrialisation. In this paper the GDP is used to present the facet of industrialisation in economic development. As the literature confirms, pre-industrial modes 
of social reproduction are destroyed as a consequence of industrialisation. Making the development of the welfare state a necessity.

\section{Trade Openness}

There is an on-going discussion among scholars about the impact of trade openness on government public spending between countries with different income levels. One of the most supported theses argues that increases in trade openness lead governments to cut public spending in a series of goods and services, the so-called efficiency hypothesis. This has the effect of reducing the prices of intermediate and consumer goods, reducing the price of labour and ensuring exchange rates that allow to maintain competitive prices for domestic goods on the market (Rudra, 2002; 2005; in Nooruddin and Simmons, 2009: 843).

There is also a second thesis, which argues the existence of a positive relationship between trade openness and public spending. This idea was originally proposed by Cameron (1978) but was Rodrik (1998) who first confirmed the matter through a detailed investigation. Rodrik (1998: 998) concluded that there is a positive correlation between trade openness and the scope of government because the countries exposed to greater 'external risk' demand more government intervention in the form of social security. Based on the theory of compensation, Kaufman and Segura-Ubiergo (2001) suggested that greater openness to trade can encourage the use of social spending to promote the skill level and productivity of the workforce. To the extent that public investment in human capital provides a collective good for the private sector, as it will reinforce the manual skills of the workers, ensure political stability and improve economic competitiveness in the international market.

In contrast to the positive relationship between levels of trade openness and welfare state development in high-income countries (Cameron, 1978; Katzenstein, 1985; Garret, 2000; Rodrik, 1998), the historical relations between these variables in Latin America differ (Segura-Ubiergo, 2007: 35) and therefore display greater similarity to the aforementioned 
first thesis. According to Huber (1996: 144) the Latin American case is different because welfare systems in the region expanded in the majority of countries following the import substitution industrialisation policies. Thus, Latin American countries reduced their trade openness as the welfare policies consolidated and expanded. This does not mean that the Latin American experience supports the statement about the causal existence between lower trade openness and greater public spending. But due to the development model followed by countries in the region, economic development and industrialisation implied the protection of domestic production.

In addition and based on Hecksher-Ohlin theory, Rudra (2002) affirms that trade openness profoundly affects the collective action of the labour movement, thus damaging its political capacities to demand more and better social benefits through redistributive state-led welfare policies.

The sum of imports and exports (i.e. the total trade) divided by the real GDP at 2005 prices was used to verify the possible conditionality of trade openness on the degree of welfare state development in the region. Data refer to the average trade openness in the preglobalisation era (1950's-1970's), and comes from the Penn World Table 7.0 (Heston et al., 2011). As with the economic/industrial development variable, the values used to operationalise trade openness are at 2005 constant prices in order to avoid distortions caused by inflation.

In the QCA, countries with a trade openness above the sample mean are considered as countries with a relatively high openness, while countries with a trade openness below the sample mean are considered as countries with relatively low openness. Table 2 shows the results of the countries between 1950's and 1970's. 


\section{Democracy}

Unlike the OECD, Latin America and the Caribbean experimented considerable variation in terms of the democratic experience during the 1940s-1970s. Some countries have practically remained a liberal democracy since the late 1940s (e.g. Costa Rica), others have experienced democratic governments in much of the period, although with autocratic interludes (e.g. Uruguay, Chile, Venezuela) and other countries have not experienced a democratic regime during this period (e.g. Paraguay, Mexico, Guatemala). Consequently it is important to consider democracy as an explanatory variable.

It is expected that democracy is associated with the expansion of social welfare from the demand side and the supply side. From the demand side, it can be argued that in a democracy civil society groups can organise themselves freely, mobilise and demand more and better social benefits from the state. From the supply side, it can be argued that in a democracy the elected politicians are more sensitive to the demands of the poor and middle class because of the desire to remain in power or gain power. Therefore it is expected that in democracy, politicians are more incentivised to draft social welfare policies in order to improve the living conditions and quality of live of their constituents (Segura-Ubiergo, 2007: 38).

Democracy has a strong positive association with social spending in Latin America, particularly with elements that reinforce human capital formation (Avelino et al., 2005). Dietrich (2008: 407) reaffirms this relationship. Huber and Stephens (2012) show that democracy -along with the rise of leftist parties- is one of the most important determinants of the redistributive social policy in Latin America, mainly because they open the window of opportunity to develop social policy and to articulate the demands of the population. 
Democracy facilitates the existence of a party government -that according to Huber and Stephens (2001) proved to be the main explanatory variable of social development in western high income countries-, which in turn enables vertical accountability and party competition to govern. That is why the demands of the population to develop social policy are more feasible with democracy.

Over time, scholars have developed a huge variety of definitions and typologies for the term 'democracy' (e.g. Schumpeter, 1950; Sartori, 1973; Dahl, 1971 ). Generally, they are normative definitions lacking from empirical approaches. In contrast to the two economic variables discussed above, democracy is not a concept that can be quantified so easily. Mainwaring et al. (2001) solved this problem after operationalizing the concept of democracy for the region and classifying governments of nineteen Latin American countries as democracies, semi-democracies or autocracies. They define democracy as a 'regime a) that sponsors free and fair competitive elections for the legislature and executive; b) that allows for inclusive adult citizenship; c) that protects civil liberties and political rights; and d) in which the elected governments really govern and the military is under civilian control' (Mainwaring et al., 2001: 38).

According to the authors this trichotomous regime classification offers advantages over the classic dichotomous categorisation because it capture better the significant variations in regimes, especially when they fall into the semi-democratic buffer zone. The semidemocratic category includes a variety of regimes that promote competitive elections while other elements of democracy are missing or are deteriorated (Mainwaring et al., 2001: 50).

In the QCA countries are analysed according to the number of years under democracy between the decades of 1950's-1970's, using Mainwaring et al. (2001) as the main reference. Countries with democratic governments during seventeen years and a half or more (sample mean) are considered as countries with a relatively high democratic experience, while 
countries that experienced a democratic government in less than seventeen years and a half are considered as countries with relatively low democratic experience. Table 2 shows the results of the countries between 1945 and 1979.

\section{Strength of labour movements and leftist parties}

Unlike the institutionalist and structuralist perspective, several scholars have argued for the usefulness of social democratic theory or power resources theory to explain the welfare state development. Esping-Andersen (1993: 34) does not consider the role of social classes as the main agents of change in welfare state development but instead argues that the guarantees of social rights facilitates the decommodification of welfare through the leadership of the labour movement -organised as a power resource.

Huber et al. (1993: 714) points out the importance of power resources theories to understand the degree of welfare state development. The theory of power resources argues that the level of mobilisation of the working class and the strength of the leftist parties are the main determinants of the size and distributional impact of the welfare state (Korpi, 1983). Cameron (1978) also shows the significant impact the strength of leftist parties have on the degree of welfare state development. Huber and Stephens (2001) go further by proving that leftist government incumbency was the most significant and important factor in the expansion of the welfare state in Western Europe. While this must not necessarily be the same in Latin America, it is at least an important precedent to consider.

According to Segura-Ubiergo (2007) there are two main reasons why it is much more difficult to assess the importance of the strength of labour movement and leftist parties in Latin America in comparison with European and North American countries. First because of the scarcity of labour union data, and second, because the limited institutionalisation of political parties blurry the understanding of partisan orientation changes over time. In order 
to operationalize the strength of the labour movement and the power of leftist parties without the need of unionisation data, Segura-Ubiergo built the Left-Labour Power Index.

The Left-Labour Power Index is composed of two indicators. First, the labour strength index that presents labour union strength combining four indicators through principal component analysis. Second, the vote received by left and centre-left parties in all elections of the lower house or constitutional assembly from 1945 to 1979 . While the labour strength index displays a representation of the labour movement strength in Latin America, it is still an index made up of four proxies of the respective variable. In this paper, trade union density (percentage of workers enrolled at a labour union) is considered a more effective indicator to operationalize the variable 'strength of labour movement'.

McGuire (1999a; 1999b; 2002) publications and databases made it possible to obtain union density data for two years in two subsequent decades within the pre-globalisation period. The limited collection of statistical data (e.g. censuses, surveys) in Latin America during this period is the main cause for the scarcity of data related to left-labour power: number of unionised workers, the total number of employees, as well as the economically active population. One of the clearest examples of the vague data collection in the region is exemplified by Bolivia, where only two censuses (1950 and 1976) were conducted over the pre-globalisation era.

Now, what is union density and why consider it as an indicator to measure the strength of labour movement? According to the OECD Labour Force Statistics, trade union density is the quotient between the proportion of salaried unionised workers and the total salaried employees in the country.

Further recalls that trade union density is an important determinant in the political arena as well as in the market (Wallerstein, 1989: 481-482). A high union density gives unions a greater ability to disrupt the economy, more freedom from the 'free-rider' and from obstacles 
to collective action, more resources for electoral campaigns and lobbying, and more power to make preferential concessions for government policies (Hicks and Swank, 1984: 89-90). It is generally understood that as the ratio of workers affiliated to trade unions increases the bargaining power on labour issues also increases (Rose and Chaison, 1996; Sullivan, 2010).

The Labor-Left Strenght Index is used as an indicator of the strenght of labor movements and leftist parties. The index was constructed by the additive combination of a) the union density average (1950's-1960's) -indicator of labor movement as a syndicalised and institutionalised power resource- and b) the percentage of votes for left and center-left parties in elections between 1945-1979 -indicator of labor movement as a political power resource. In the QCA countries are analysed according to the Labour-Left Strength Index. Countries with Labor-Left Strenght Index values higher than 0.50 are considered as countries with a relatively high labor-left strenght, while countries values lower than 0.50 are considered as countries with relatively low labor-left strenght. Table 2 shows the results of the countries for the pre-globalisation era.

\section{Methods: Qualitative Comparative Analysis}

According to Ragin (2006) in the qualitative comparative analysis (QCA) each case is represented as the combination of causal conditions and expected results. The purpose of this technique is to translate the information from data into a truth-table where different combinations of conditions that produce a specific result can be identified. In this research QCA is used to evaluate the possibility of identifying a common path of political and economic conditions that produce specific degrees of welfare state development in the region.

QCA is a case-oriented approach; therefore it is useful to perform analysis on small-N studies. One of the main limitations of this technique is related to the conditions considered as explanatory variables. According to Kane et al. (2014:207) QCA must be theory-driven 
and bounded by priority questions because every additional condition included increases exponentially the number of possible combinations for the desired outcome. In order to avoid this limitation -commonly known as limited diversity-, section 4 included a detailed explanation of the selected explanatory variables.

Ragin (1987: 84) intention was to develop a strategy as a midpoint between the casesoriented approaches (qualitative) and variables-oriented approaches (quantitative) were best features of both could be integrated in one method. Ragin (1987) rejects the argument that through QCA a single causality is determined, rather a number of different paths that might have allowed the corresponding final outcome is determined. In other words, this paper examines the different paths of political and economic variables in the countries during the pre-globalisation era that might have conditioned a specific outcome: a low, intermediate or high degree of welfare state development.

Causal relationships between political and economic conditions (explanatory variables) and the degree of welfare state development were examined through Boolean algebra principles and comparative analysis. Ragin proposed a series of qualitative data binary matrices $(0,1)$ to describe the presence or absence of certain characteristics or conditions. Thus the original values of the seventeen countries on the four explanatory variables are replaced by ' 1 ' and ' 0 '. A case exhibits a ' 1 ' in the explanatory variable presenting the favourable features for the desired outcome. Therefore, cases with a ' 0 ' in the explanatory variable exhibit unfavourable features for the desired outcome.

A multiple truth-table with the three possible outcomes of the MWI is constructed showing the favourable (1) and unfavourable (0) conditions for the specific welfare outcome (see Table 3). The truth-table reveals a binary map with the combination of conditions necessary to present a relatively high, medium or low welfare state development. In addition a four levels figure -one level for each explanatory variable- is built to display and trace 
more easily than with the truth-table the path followed by countries with a relatively high, medium and low level of welfare state development. Figure 1 not only helps identify the diverse trajectories but also facilitates the contrast of results with those obtained by SeguraUbiergo.

-Table 3-

-Figure 1-

\section{Results and contrasts with the findings of Segura-Ubiergo (2007)}

After analysing the data presented in Table 3 and Figure 1, it is not possible to identify a common path of favourable economic and political conditions followed by the four countries with a MWI higher than 0.66. The discrepancy is even greater in countries with an intermediate welfare state development. However, countries with a relatively low welfare state development followed a similar path of unfavourable economic and political conditions during the pre-globalisation era. The eight countries with a MWI score smaller than 0.33 showed a low economic/industrial growth combined with a low democratic experience in the truth-table. In a linear least squares regression analysis (not shown here) these two were the only variables with a highly significant and strong negative correlation with the MWI (pvalue $<0,01)$.

Segura-Ubiergo (2007) managed to define a common path followed by countries with high welfare effort using the same four political and economic conditions. According to the author, countries with a high welfare effort experienced the following characteristics during the pre-globalisation era (1940-1970's):

a) Two favourable economic conditions and a favourable political conditions. Uruguay, Costa Rica, Brazil and Argentina were the countries following this path.

b) Two favourable political conditions and none of the favourable economic conditions. Chile was the country following this path. 
The previous paragraph clearly points out the mixed findings between Segura-Ubiergo and this paper. Several issues must be considered to explain why the results and conclusions between the two studies are different. a) The dependent variable used by Segura-Ubiergo was an index of welfare effort based primarily on indicators of social spending, whereas in this study a multidimensional index was considered to present the relative development of the welfare state. b) Segura-Ubiergo used three fewer cases in his analysis (did not included Colombia, Panama or Puerto Rico). So the inclusion of more countries from the region may have altered his findings. c) Furthermore, Segura-Ubiergo considered two possible outcomes to analyse the paths (high and low welfare effort), while three possible outcomes are considered in the present study (high, medium and low welfare state development). d) Finally, some of the variables in this study are operationalized using different indicators and/or sources to those used by Segura-Ubiergo.

Below are some of the differences with Segura-Ubiergo's study regarding the operationalization of political and economic conditions:

a) Segura-Ubiergo used the average from 1930-1999 to calculate the 'economic/industrial development' variable. If the author's purpose was to analyse how these four conditions affected/conditioned the degree of welfare effort during the pre-globalisation era (1945-1979), why to include data from the 1930's, 1980's and 1990 's? Therefore, this variable is operationalized in this article using the period referenced by the author: 1940s-1970s.

b) Segura-Ubiergo used a cut-off point of 30 per cent to distinguish between cases with high and low trade openness. However, in this study the sample mean is used to divide cases between high and low trade openness. In addition the sources and data used by Segura-Ubiergo does not correspond to those outlined in this paper. Possibly the main reason is that trade openness data as well as economic development data in 
this paper, are adjusted to 2005 constant prices in order to reduce distortions caused by inflation through the period.

c) Perhaps the most noticeable difference was changing the method of calculating the strength of the labour movement and leftist parties. Instead of a composite indicator as a rough proxy of labour movement strength, this paper used trade union density to measure the labour movement strength. Combined with the votes obtained by the left and centre-left, the Left-Labour strength index was constructed.

\section{Conclusion}

Having briefly presented the multidimensional welfare index for the period 1980's-2000's, its indicators, dimensions and results, the paper proceeded to analyse whether it was actually possible to trace a common path followed by countries with a similar degree of welfare state development. Segura-Ubiergo's work was used as the starting point for this analysis.

Unlike Segura-Ubiergo's findings, this article concludes that it was not possible to identify a common path of economic and political conditions during the era of the preglobalisation (1945-1979), followed by countries with relatively high and intermediate level of welfare state development. However, through QCA this paper confirmed the existence of a common path followed by countries with a relatively low welfare state development (MWI score less than 0.33): Colombia, Ecuador, Peru, Dominican Republic, El Salvador, Bolivia, Guatemala and Paraguay. These countries experienced a combination of relatively low democratic experience (seventeen years and a half or less) with relatively low economic/industrial development (average GDP per capita PPP at 2005 constant prices lower than the sample average: $\$ 4,472.39$ ) during the pre-globalisation era, and were conditioned to exhibit a relatively low welfare state development during the 1980's - 2000's. 
Panama was the only country with a relatively low economic/industrial development and a relatively low democratic experience that did not exhibited a relatively low welfare state development in the 1970's-2000's era. Therefore it can be argued that according to the sample and the period analysed the combined absence of these two favourable conditions for welfare state development during the pre-globalisation era explain with a 88.89 per cent the likelihood that a country showed up a relatively low welfare state development in the 1980s2000s period.

There are two main messages deriving from the results of the paper. First, it is of utmost importance to conceptualise and operationalize the welfare state by its multidimensional reality. By rejecting Segura-Ubiergo's findings, this paper confirms that social spending (welfare effort) is not enough to explain the multidimensionality behind welfare state development. Second, relatively low levels of democratisation and industrialisation appear to be the main reason behind the relatively low welfare state development of eight Latin American and Caribbean countries.

Future research on the subject will be necessary to evaluate other explanatory variables in addition to the four used by Segura-Ubiergo. Mainly explanatory variables that take into account the features of the emerging welfare state in Latin American and Caribbean. Calculating the multidimensional welfare index in shorter periods would make possible the introduction of further quantitative analysis (e.g. time series regression analysis) with this or alternative explanatory variables. In addition, it would be relevant to examine the puzzle behind Panama in this study (i.e. the combined unfavourable conditions with an intermediate welfare state development). Does the influence of the US, the Panama Canal, and/or the remittances could help explain this puzzle?

The important thing is to continue considering the 'welfare state development' as a multidimensional variable and thus overcame the limitations by not operationalizing it with 
only indicators of social spending. The scarcity of data in Latin America is real, but this is no excuse to conceptualise a variable only by one of its dimensions. Let's name things for what they are. Social spending may represents the welfare effort of a state as Segura-Ubiergo indicates, but it does not make justice to the multidimensional nature of the welfare state.

\section{References}

Alba, V. (1968) Poitics and the Labor Movement in Latin America. Stanford University Press: Stanford.

Atkinson, A. (1995) The Economics of the Welfare State. Frank E. Seidman Lecture. Rhodes College, Memphis, TN.

Avelino, G., D.S. Brown and W. Hunter. (2005) The Effects of Capital Mobility, Trade Openness, and Democracy on Social Spending in Latin America, 1980-1999. American Journal of Political Science 49(3): 625-641.

Ayala, C.J. and R. Bernabe. (2009) Puerto Rico in the American Century: A History since 1898. University of North Carolina Press: Chapel Hill.

Barba Solano, C. (2009) 'Los regímenes de bienestar latinoamericanos y la reforma social' in Barba Solano, C., G. Ordoñez Barba and E. Valencia Lomelí (eds.) Más allá de la pobreza: Regímenes de bienestar en Europa, Asia y América. Universidad de Guadalajara, El Colegio de la Frontera Norte: Guadalajara, 327-370.

Bauman, Z. (2014) ¿La riqueza de unos pocos nos beneficia a todos? Ediciones Paidós Ibérica, S.A: Barcelona.

Bértola, Luis and José Antonio Ocampo (2012) The Economic Development of Latin America Since Independence. Oxford University Press: Oxford. 
Bregar, L., J. Rovan and M. Pavsic. (2008) Validity of GDP per capita for International Development Comparisons. Economic and Business Review for Central and South Eastern Europe 10(3): 181-195.

Cameron, D.R. (1978) The Expansion of the Public Economy: A Comparative Analysis. American Political Science Review 72(4): 1243-1261.

Cecchini, S., F. Filgueira, R. Martinez, and C. Rossel (2015) Instrumentos de protección social. Caminos Latinoamericanos hacia la universalización, CEPAL: Santiago de Chile.

CEPAL/CELADE. (2000) América Latina: Población por años calendario y edades simples 1995-2005. Boletín Demográfico (66).

Coppedge, M. (1997) A Classification of Latin American Political Parties. Working Paper \#244, Kellogg Institute.

Cruz-Martinez, G. (2014) Welfare State Development in Latin America and the Caribbean (1970s-2000s): Multidimensional Welfare Index, Its Methodology and Results. Social Indicators Research 119(3): 1295-1317.

Cruz-Martinez, G. (2015) Análisis Multidimensional del Estado de bienestar emergente y la pobreza en América Latina y el Caribe: Puerto Rico como estudio de caso. Unpublished doctoral dissertation, Universidad Complutense de Madrid, Madrid, http://eprints.ucm.es/30004/ [accessed 15 February 2016].

Dahl, R. (1971) Poliarchy, Participation and Opposition. Yale University Press: New Haven. Denis, N.A. (2015) War Against all Puerto Ricans: Revolution and Terror in America's Colony. Nation Books: New York.

Dietrich, R. (2008) Democracy and Social Welfare. Contemporary Sociology 37(5): 407-410. Esping-Andersen, G. (1990) The Three Worlds of Welfare Capitalism. Princeton University Press: New Jersey 
Fleitas, S. and C. Roman. (2010) Evolución de la población económicamente aciva en el siglo XX: Un análisis de la estructura por sexo, edad y generaciones. Boletin de Historia Economica Año VIII(9): 41-64.

Garret, G. (2000) The Causes of Globalization. Comparative Political Studies 33(6/7): 941991.

Haggard, S. and R.R. Kaufman. (2009) Development, Democracy, and Welfare States: Latin America, East Asia, and Eastern Europe. Princeton University Press: New Jersey.

Heston, A., R. Summers and B. Aten. (2011) Penn World Table Version 7.0. Center for International Comparisons of Production, Income and Prices at the University of Pennsylvania.

Hicks, A. and D. Swank. (1984) On the Political Economy of Welfare Expansion. Comparative Political Studies 17(1): 81-119.

Huber, E. (1996) Options for Social policy in Latin America: Neoliberal vs Social Democratic Models. In: Esping-Andersen, G. (ed.) Welfare States in Transition: National Adaptations in Global Economies. SAGE Publications: London.

Huber, E., C. Ragin and J.D. Stephens. (1993) Social Democracy, Christian Democracy, Constitutional Structure, and the Welfare State. American Journal of Sociology 99(3): 711-749.

Huber, E. and J. Stephens. (2001) Development and Crisis of the Welfare States: Parties and Policies in Global Market. University of Chicago Press: Chicago.

Huber, E. and J.D. Stephens. (2012) Democracy and the Left. Social Policy and Inequality in Latin America,.The University of Chicago Press: Chicago.

International Labour Organization. (2012) Laborsta. http://laborsta.ilo.org/default_S.html [accessed 15 February 2016]. 
Kane, H., Lewis, M. A., Williams, P. A., and Kahwati, L. C. (2014). Using qualitative comparative analysis to understand and quantify translation and implementation. Translational Behavioral Medicine, 4(2), 201-208.

Katzenstein, P. (1985) Small States in World Markets. Cornell University Press: New York. Kaufman, R.R. and A. Segura-Ubiergo. (2001) Globalization, Domestic Politics, and Social Spending in Latin America: A Time-Series Cross-Section Analysis, 1973-97. World Politics 53(4): 553-587.

Korpi, W. (1983) The Democratic Class Struggle. Routledge and Kegan Paul: London. Lamartina, S. and A. Zaghini. (2011) Increasing Public Expenditure: Wagner's Law in OECD Countries. German Economic Review 12(2): 149-164.

Mainwaring, S., D. Brick and A. Perez-Liñan. (2001) Classifying Political Regimes in Latin America, 1945-1999. Studies in International Comparative Development 36(1): 3765.

Martinez Franzoni, J. (2008) Welfare regimes in Latin America: Capturing Constellations of Markets, Families, and Policies. Latin American Politics and Society 50(2): 67-100.

Mesa-Lago, C. (1994) Changing Social Security in Latin America. Lynne Rienner Publishers: London.

McGuire, J.W. (1999a) Development Database. http://jmcguire.faculty.wesleyan.edu/welcome/data/ [accessed 15 February 2016].

McGuire, J.W. (1999b) Labor Union Strength and Human Development in East Asia and Latin America. Studies in Comparative International Development 33(4): 3-33.

McGuire, J.W. (2002) 20 Latin American Countries Database. http://jmcguire.faculty.wesleyan.edu/welcome/data/ [accessed 15 February 2016]. Molina, C.G. (2006) Universalismo básico: Una nueva política social para América Latina. Editorial Planeta / Banco Interamericano de Desarrollo: Washington D.C. 
Nooruddin, I. and J.W. Simmons. (2009) Openness, Uncertainty, and Social Spending: Implications for the Globalization-Welfare State Debate. International Studies Quarterly 53(3): 841-866.

Olaskoaga, J., R. Alaez-Aller and P. Díaz-De-Basurto-Uraga. (2013) Beyond Welfare Effort in the Measuring of Welfare States. Journal of Comparative Policy Analysis 15(3): 274-287.

Pierson, P. (2000) Increasing Returns, Path-dependence and the Study of Politics. The American Political Science Review 94(2): 251-267.

Ragin, C. (1987) The Comparative Method: Moving Beyond Quantitative and Qualitative Strategies. University of California Press: Berkeley.

Ragin, C. (2006) User's Guide to Fuzzy-Set/Qualitative Comparative Analysis 2.0, Tucson: Arizona: Department of Sociology, University of Arizona.

Riesco, M. (2009) Latin America: A New Developmental Welfare State Model in the Making? International Journal of Social Welfare 18: S22-S36.

Rodrik, D. (1998) Why do more Open Economies have Bigger Governments? Journal of Political Economy 106(5): 997-1032.

Rose, J.B. and G.N. Chaison. (1996) Linking Union Density and Union Effectiveness: The North American Experience. Industrial Relations 35(1): 78-105.

Rudra, N. (2002) Globalization and the Decline of the Welfare State in Less-Developed Countries. International Organization 56(2): 411-445.

Rudra, N. (2005) Are Workers in the Developing World 'Winners' or 'Losers' in the Current Era of Globalization. Studies in Comparative International Development 40(3): 2964.

Sartori, G. (1973) Democratic Theory, Westport, Connecticut: Greewood Press.

Schumpeter, J. (1950) Capitalism, Socialism and Democracy. Harper and Row: New York. 
Segura-Ubiergo, A. (2007) The Political Economy of the Welfare State in Latin America:

Globalization, Democracy and Development. Cambridge University Press: New York.

Sierra-Berdecia, F. (1955) Puerto Rico Labor Unions and Labor Relations. Monthly Labor Review 78(12): 1359-1362.

Sullivan, R. (2010) Labour Market or Labour Movement? The Union Density Bias as Barrier to Labour Renewal. Work, Employment and Society 24(1): 145-156.

Uriel Jiménez, E. (1995). Análisis de Datos. Series temporales y análisis multivariante. Editorial AC: Madrid.

Wallerstein, M. (1989) Union Organization in Advanced Industrial Democracies. American Political Science Review 83(2): 379-401.

Wilensky, H.L. (1975) The Welfare State and Equality: Structural and Ideological Roots of Public Expenditure.University od California Press: Berkeley. 
Table 1: Results of the Multidimensional Welfare Index (MWI) after the Arithmetic Mean of the Standardised Individual Welfare Indexes (SSDI, CDI and ODI) from 17 Countries between 1970's-2000's.

\begin{tabular}{|c|c|c|c|c|}
\hline & $\begin{array}{c}\text { SSDI }(\max =1, \\
\min =0)\end{array}$ & $\begin{array}{c}\mathrm{CDI}(\max =1, \\
\min =0)\end{array}$ & $\begin{array}{c}\text { ODI }(\max =1 \\
\min =0)\end{array}$ & $\begin{array}{c}\text { MWI }(\operatorname{Max}=1 \\
\text { Min=0) }\end{array}$ \\
\hline \multicolumn{5}{|l|}{ High Welfare State } \\
\hline \multicolumn{5}{|l|}{ Development } \\
\hline Puerto Rico & 0.93 & 1.00 & 1.00 & 0.98 \\
\hline Argentina & 0.87 & 0.97 & 0.69 & 0.84 \\
\hline Uruguay & 1.00 & 0.87 & 0.50 & 0.79 \\
\hline Chile & 0.77 & 0.76 & 0.61 & 0.71 \\
\hline Average & 0.89 & 0.90 & 0.70 & $\mathbf{0 . 8 3}$ \\
\hline \multicolumn{5}{|l|}{ Intermediate Welfare } \\
\hline \multicolumn{5}{|l|}{ State Development } \\
\hline Costa Rica & 0.73 & 0.62 & 0.53 & 0.63 \\
\hline Brazil & 0.75 & 0.63 & 0.24 & 0.54 \\
\hline Panamá & 0.30 & 0.57 & 0.46 & 0.44 \\
\hline Venezuela & 0.23 & 0.43 & 0.43 & 0.36 \\
\hline Mexico & 0.31 & 0.36 & 0.40 & 0.36 \\
\hline Average & 0.47 & 0.52 & 0.41 & 0.47 \\
\hline \multicolumn{5}{|l|}{ Low Welfare State } \\
\hline \multicolumn{5}{|l|}{ Development } \\
\hline Colombia & 0.38 & 0.10 & 0.39 & 0.29 \\
\hline Ecuador & 0.11 & 0.07 & 0.44 & 0.20 \\
\hline Peru & 0.04 & 0.12 & 0.35 & 0.17 \\
\hline Dominican Republic & 0.03 & 0.19 & 0.28 & 0.17 \\
\hline El Salvador & 0.08 & 0.13 & 0.28 & 0.16 \\
\hline Paraguay & 0.11 & 0.05 & 0.18 & 0.11 \\
\hline Bolivia & 0.21 & 0.08 & 0.00 & 0.09 \\
\hline Guatemala & 0.00 & 0.00 & 0.03 & 0.01 \\
\hline Average & 0.12 & 0.09 & 0.24 & 0.15 \\
\hline 17 Countries Average & 0.40 & 0.41 & 0.40 & 0.40 \\
\hline
\end{tabular}

Notes:

a) SSDI indicators: social spending as a percentage of GDP, social spending as a percentage of public spending and social spending per capita.

b) CDI indicators: percentage of population covered by at least a social security program, percentage of employees with retirement coverage and hospital beds per ten thousand inhabitants.

c) ODI indicators: percentage of population with high level of education, and the improbability of suffering infant mortality (under five years of age).

d) MWI is a composite indicator formed by eight indicators from three welfare dimensions and used to rank countries in terms of their relative welfare state development. 
Table 2: Relative Economic/Industrial Development, Trade Openness, Democratic Experience, and Strength of the Labour Movement and Leftist Parties in Latin America and the Caribbean on the Pre-Globalisation Era

\begin{tabular}{|c|c|c|c|c|c|c|c|c|}
\hline & \multicolumn{2}{|c|}{ Economic/Industrial development ${ }^{a}$} & Trade Openness ${ }^{b}$ & $\begin{array}{l}\text { Democratic } \\
\text { experience }^{c}\end{array}$ & \multicolumn{4}{|c|}{ Labour-Left Strength Index (LLSI) ${ }^{d}$} \\
\hline & Average 1950s-1970s & $\begin{array}{c}\text { Standardised } \\
\text { average }(\%)\end{array}$ & $(\%)$ & (years) & $\begin{array}{l}\text { Union Density } \\
1950 \text { 's-1960`s }\end{array}$ & $\begin{array}{l}\text { Vote to } \\
\text { the left }\end{array}$ & LLSI & $\begin{array}{c}\text { LLSI }(\max .=1, \\
\min =0)\end{array}$ \\
\hline Argentina & 7034.63 & 157.29 & 15.14 & $2 / 35$ & 0.49 & 0.26 & 0.75 & 0.74 \\
\hline Bolivia & 3053.66 & 68.28 & 46.80 & $0 / 35$ & 0.24 & 0.78 & 1.01 & 1.00 \\
\hline Brazil & 3992.07 & 89.26 & 10.44 & $18 / 35$ & 0.10 & 0.11 & 0.21 & 0.20 \\
\hline Chile & 4082.83 & 91.29 & 25.54 & $28 / 35$ & 0.19 & 0.37 & 0.56 & 0.55 \\
\hline Colombia & 2818.04 & 63.01 & 22.90 & $6 / 35$ & 0.18 & 0.02 & 0.20 & 0.19 \\
\hline Costa Rica & 5705.01 & 127.56 & 33.30 & $31 / 35$ & 0.04 & 0.52 & 0.55 & 0.54 \\
\hline Dominican & & & & & & & & \\
\hline Republic & 2695.86 & 60.28 & 67.79 & $2 / 35$ & 0.06 & 0.00 & 0.06 & 0.05 \\
\hline Ecuador & 3239.18 & 72.43 & 37.82 & $14 / 35$ & 0.06 & 0.11 & 0.16 & 0.15 \\
\hline El Salvador & 3958.96 & 88.52 & 34.99 & $0 / 35$ & 0.03 & 0.00 & 0.03 & 0.02 \\
\hline Guatemala & 3687.60 & 82.45 & 61.33 & $0 / 35$ & 0.01 & 0.00 & 0.01 & 0.00 \\
\hline Mexico & 5549.18 & 124.08 & 14.31 & $0 / 35$ & 0.16 & 0.26 & 0.43 & 0.42 \\
\hline Panama & 2812.11 & 62.88 & 167.90 & $0 / 35$ & 0.03 & 0.00 & 0.03 & 0.02 \\
\hline Paraguay & 2099.85 & 46.95 & 43.27 & $0 / 35$ & 0.10 & 0.00 & 0.10 & 0.09 \\
\hline Peru & 4392.41 & 98.21 & 32.38 & $5 / 35$ & 0.06 & 0.61 & 0.67 & 0.66 \\
\hline Puerto Rico & 7718.30 & 172.58 & 125.19 & $22 / 35$ & 0.24 & 0.10 & 0.34 & 0.33 \\
\hline Uruguay & 4927.30 & 110.17 & 23.58 & $28 / 35$ & 0.15 & 0.47 & 0.62 & 0.60 \\
\hline Venezuela & 8263.73 & 184.77 & 52.68 & $23 / 35$ & 0.15 & 0.70 & 0.84 & 0.83 \\
\hline $\begin{array}{l}\text { Average - } \\
\text { High e }^{\text {e }}\end{array}$ & 6533.02 & 146.07 & 94.98 & 25 & 0.19 & 0.53 & 0.72 & 0.70 \\
\hline $\begin{array}{l}\text { Average - } \\
\text { Low }^{\mathrm{e}}\end{array}$ & 3348.42 & 74.87 & 28.37 & 2.60 & 0.09 & 0.06 & 0.16 & 0.15 \\
\hline
\end{tabular}


17 countries

average

4472.39

100

47.96

16.30

0.13

0.25

0.39

0.38

Prepared by the author with own observations and calculations; Source: (Heston et al., 2011, Mainwaring et al., 2001, Alba, 1968; Sierra-Berdecia, 1955;

CEPAL/CELADE, 2000; Fleitas and Roman, 2010; Coppedge, 1997; International Labour Organization, 2012; McGuire, 1999a; 2002) Notes:

a) GDP per capita at purchasing power parity and 2005 constant prices (1950s-1970s average). The second column is a standardized version (average $=100$ ).

b) Sum of imports and exports divided by the real GDP at 2005 prices. Data from the PWT ('openk') (1950s-1970s average).

c) The total number years in democracy during the 1945-1979. Puerto Rico is the only case in the sample that was not considered by these scholars. After the first elections in 1949 the first element of democracy according to Mainwaring et al. (2001) was guaranteed. It was not until the derogation of Law 53 of 1948 when the civil liberties and political rights started to be de jure guaranteed to all individuals. Since 1948 to 1957 the Law 53 permitted the persecution and violation of civil rights and political rights of social movements in the left ideology spectrum and social groups in favour of Puerto Rico's independence. See Ayala and Bernabe (2009) and Denis (2015) for a detailed history of the period, facts and analyses.

d) Trade union density refers to the proportion of union members on the economically active population. Union density 1950 's-1960's' is the average for the period using the data available. Vote to the left refers to the percentage of votes received by the Centre-Left and Left in all elections of the lower house or constitutional assembly from 1945 to 1979. The coding from Coppedge (1997) was used to locate the parties in the political spectrum. The case of Puerto Rico refers only to the elections of the executive branch and was coded by the author. LLSI is an additive index combining the average of trade union density and the vote to the left.

e) 'Average - High' refers to the average score of countries with a relatively high industrial development, trade openness, democratic experience, and strength of the labour movement and leftist parties. 'Average - Low' refers to the average score of the countries in each of the four explanatory variables. 
Table 3: Favourable Political and Economic Conditions for the Development of the Welfare State in Latin America and the Caribbean: Historical Experience in a Truth-Table

\begin{tabular}{|c|c|c|c|c|c|c|c|}
\hline \multirow[b]{2}{*}{ Countries } & \multicolumn{2}{|c|}{$\begin{array}{c}\text { Favourable Political } \\
\text { Conditions }\end{array}$} & \multicolumn{2}{|c|}{$\begin{array}{c}\text { Favourable Economic } \\
\text { Conditions }\end{array}$} & \multicolumn{3}{|c|}{ Outcome } \\
\hline & $\begin{array}{c}\text { High } \\
\text { democratic } \\
\text { experience }\end{array}$ & $\begin{array}{c}\text { High } \\
\text { Labour- } \\
\text { Left } \\
\text { Strength }\end{array}$ & $\begin{array}{c}\text { Low } \\
\text { trade } \\
\text { openness }\end{array}$ & $\begin{array}{c}\text { High } \\
\text { economic } \\
\text { development }\end{array}$ & $\begin{array}{l}\text { High } \\
\text { WSD }\end{array}$ & $\begin{array}{l}\text { Intermediate } \\
\text { WSD }\end{array}$ & $\begin{array}{l}\text { Low } \\
\text { WSD }\end{array}$ \\
\hline Argentina & 0 & 1 & 1 & 1 & 1 & 0 & 0 \\
\hline Bolivia & 0 & 1 & 1 & 0 & 0 & 0 & 1 \\
\hline Brazil & 1 & 0 & 1 & 0 & 1 & 1 & 0 \\
\hline Chile & 1 & 1 & 1 & 0 & 1 & 0 & 0 \\
\hline Colombia & 0 & 0 & 1 & 0 & 0 & 0 & 1 \\
\hline Costa Rica & 1 & 1 & 1 & 1 & 0 & 1 & 0 \\
\hline $\begin{array}{l}\text { Dominican } \\
\text { Republic }\end{array}$ & 0 & 0 & 0 & 0 & 0 & 0 & 1 \\
\hline Ecuador & 0 & 0 & 1 & 0 & 0 & 0 & 1 \\
\hline El Salvador & 0 & 0 & 1 & 0 & 0 & 0 & 1 \\
\hline Guatemala & 0 & 0 & 0 & 0 & 0 & 0 & 1 \\
\hline Mexico & 0 & 0 & 1 & 1 & 0 & 1 & 0 \\
\hline Panama & 0 & 0 & 0 & 0 & 0 & 1 & 0 \\
\hline Paraguay & 0 & 0 & 1 & 0 & 0 & 0 & 1 \\
\hline Peru & 0 & 1 & 1 & 0 & 0 & 0 & 1 \\
\hline Puerto Rico & 1 & 0 & 0 & 1 & 1 & 0 & 0 \\
\hline Uruguay & 1 & 1 & 1 & 1 & 0 & 0 & 0 \\
\hline Venezuela & 1 & 1 & 0 & 1 & 0 & 1 & 0 \\
\hline
\end{tabular}

Note: WSD refers to welfare state development. 
Figure 1: Favourable Political and Economic Conditions for the Welfare State Development in Latin America and the Caribbean: Four-Level Diagram after QCA

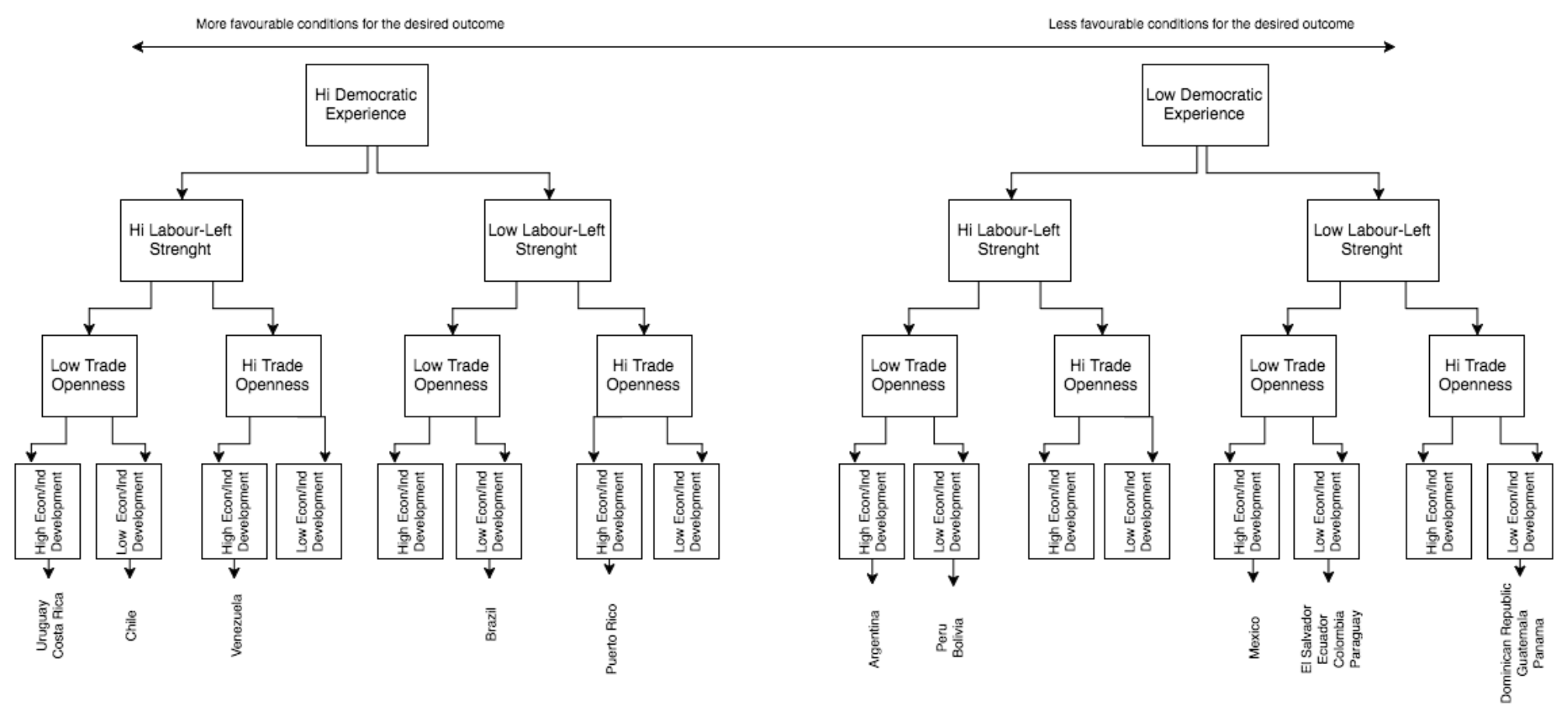

Prepared by the author using the truth-table in Table 3 